\title{
O xamanismo kaingang como potência decolonizadora
}

\section{Kaingang shamanism as a decolonial potentiality}

Clémentine Ismérie Maréchal ${ }^{\star}$

* Universidade Federal do Rio Grande do Sul - Porto Alegre, RS, Brasil Doutoranda em Antropologia Social clementine.marechal08@gmail.com

Herbert Walter Hermann ${ }^{* *}$

** Universidade Federal do Rio Grande do Sul - Porto Alegre, RS, Brasil Doutorando em Antropologia Social herbertwh@gmail.com 


\title{
Resumo
}

Este trabalho propõe, através de exemplos etnográficos, entender o xamanismo kaingang como expressão cosmopolítica nos processos históricos coloniais. As etnografias produzidas junto aos Kaingang apresentam evidências similares sobre o profundo caráter "político" da práxis xamânica kaingang. Analisando criticamente o conceito de xamanismo ressaltamos os termos e os acontecimentos entre os Kaingang para falar sobre seus saberes e conhecimentos, abordamos aqui os vẽnh péti (sonhos) entre os kujà ("xamã") como um possível impulso decolonial. Além dos casos etnográficos e das pesquisas publicadas percorremos relatos míticos de uma kujà sobre o nascimento do xamanismo kaingang e as ações da comunidade kaingang para salvar a humanidade da escuridão, restituindo de maneira precisa e situada tanto o protagonismo feminino quanto o desejo dos Kaingang na existência de um futuro compartilhado em ga.

Palavras-chave: xamanismo; Kaingang; colonialidade; cosmopolítica.

\begin{abstract}
The different ethnographic studies focusing on the Kaingang people pointed out similar evidence concerning the deep political nature of their shamanic praxis. By presenting ethnographical cases, this article emphasizes the implication of Kaingang shamanism as a cosmopolitical expression involved the historical colonial process. A critical analysis of the shamanism concepts is conducted here with a proper terminology and illustrates the point of view of the Kaingang people on this topic. In particular, the concept of vẽnh péti (dreams) experienced by the kujà ("shaman") is presented as a possible decolonization impulse. More than a review of ethnographical studies, this paper proposes the mythical narration of a kujà about the birth of Kaingang shamanism and the measures taken by this community to save humanity from darkness, giving back to them political feminine protagonist and the wishes of a decolonial future in $g a$ (the Earth).
\end{abstract}

Keywords: shamanism; Kaingang; coloniality; cosmopolitics. 


\section{Introdução}

Os Kaingang, "gente do mato", são um povo indígena jê meridional que pertence ao tronco linguístico macro-jê, em termos quantitativos compõe na atualidade uma das populações indígenas mais numerosas no Brasil, com aproximadamente 40 mil pessoas. Ocupam um território que abrange os estados do Rio Grande do Sul, de Santa Catarina, do Paraná e do sul de São Paulo, em porções urbanas e "acampamentos" onde estão aguardando a tramitação da demarcação e homologação das suas terras pelo Estado brasileiro. Muitas famílias kaingang moram porém, em Terras Indígenas (TI), espaços territoriais "oficiais", que emergiram, às vezes, como resultados de iniciativas missionárias a partir de meados do século XIX, para concentração e redução dos indígenas, com o objetivo de "disponibilizar" terras para imigrantes italianos e alemães (Fernandes, 2003). Em consequência de diversos processos coloniais, a partir da segunda metade do século XX, várias famílias saíram das TI e constituíram "novas" comunidades, ymã, no seu território ancestral, algumas delas em porções urbanas. Muitas dessas famílias, hoje, ainda seguem lutando pelo acesso à sua terra e autonomia, em sua maioria sofrendo a pressão do agronegócio e da especulação imobiliária, tanto rural quanto urbana, com certa anuência, e diversas vezes com promoção, das instituições brasileiras.

Um dos traços mais marcante da socialidade ${ }^{2}$ kaingang encontra-se na complementariedade ancorada no seu sistema cosmológico dualista (Silva, 2002), dividindo-se entre as metades Kamé (a metade vinculada a rã, o sol) e Kanheru-Kré (a metade vinculada a kysã, a lua). As duas metades, na medida em que se opõem, também se complementam. ${ }^{3}$ A literatura especializada apresenta diversos

1 Segundo Zaqueu Key Claudino (2013), o termo kaingang significa, no sentido literal da palavra, pessoa indígena que faz parte de qualquer um dos povos indígenas ou gente do mato, comedor de pinhão.

2 Ver Viveiros de Castro (2002, p. 295-316).

3 Diversos antropólogos ressaltaram uma assimetria entre as duas metades, a metade Kamé seria "superior" hierarquicamente à metade Kanheru-Kré (Borba, 1908; Crépeau, 2006; Rosa, 2005). Estudos baseados sobre o mito de origem kaingang e o mito sobre o nascimento da lua (disponibilizado por Dorvalino Reféj em: multileituraskaingang.blogspot.com.br/2011/07/lenda-kaingang-o-sol-e-lua-ra-e-kysa.html) no qual Rã e Kysã, dois irmãos sóis brigaram culpando-se por uma seca que acontecia na terra. Na briga, Kysã acabou ferido e enfraqueceu e Rã se tornou o único a poder iluminar o dia. Porém, ao perguntar sobre essa assimetria aos nossos interlocutores, (pertencentes à metade Kanheru-Kré), eles afirmaram que não existia nenhuma assimetria entre as duas metades, nos apresentaram outro mito de origem do sol e da lua, no qual as partes não seriam irmãos, mas sim um casal. Ver Maréchal (2018). 
exemplos dessa operatividade cosmológica, em termos sociais, o casamento é um deles, pois é vedada a união entre pessoas da mesma metade. Da mesma maneira, as relações de afinidade ideais ocorrem entre pessoas de metades distintas, o ego nomeia esse outro complementar sociocosmológico como jamré. Por ser considerada uma base fundamental do modo de ser kaingang, kanghág jykré, o dualismo e a complementariedade entre metades exogâmicas também se revela fundamental na sua prática política-xamânica, que detalharemos mais à frente.

Se, para alguns antropólogos, o conceito de "xamanismo" é recorrente para fazer referência a um sistema cosmo-ontológico, no qual se desenvolve uma série de práticas e saberes agenciados por uma pessoa especial, cujo dom lhe outorgue certo poder para se relacionar com seres de outros mundos e tempos (Silva, 2002, 2014), para determinados Kaingang, e não obstante diversos indígenas da América Latina, o uso genérico do conceito pode resultar bastante incômodo. Um dos questionamentos, cada vez mais comuns, que fazem esses indígenas, se relaciona ao uso genérico e descontextualizado do termo "xamanismo". De fato, o termo "xamã" vem da língua tunguska, oriunda do nordeste siberiano. Se encontra etimologicamente ligado à ideia de movimento, agitação e mediação entre o mundo humano e o mundo dos espíritos, o mundo "aqui" e o mundo "outro" (Chaumeil, 2000; Langdon, 1996; Perrin, 1988; Rosa, 2005). Questiona-se, então, a partir de lugares de fala distante do nordeste da Sibéria, o uso de um conceito criado por pessoas afastadas de uma realidade e de um contexto cultural local, para falar sobre práticas e saberes específicos que se encontram relacionados histórica, cultural e socialmente a contextos locais e situados.

O problema não parece residir tanto no conteúdo dos significados do conceito, mas sim no uso de um termo de maneira quase universal, que devido a esse uso exclui os próprios conceitos específicos como se eles não tivessem valor científico (Lima, 2011). Os Kaingang não são os únicos a fazer tal observação, os Mapuche também fazem essa observação. Preferem com isso tornar visíveis seus próprios conceitos e as práticas situadas a partir deles. Para fins de aprofundamento do "xamanismo" kaingang resgataremos as noções de kujà, ${ }^{4}$

4 Como será explicitado no decorrer do texto, o conceito de kujà se refere às lideranças espirituais kaingang. O termo é comumente traduzido pelos Kaingang como "pajé". Ele faz referência a uma matriz de saberes e conhecimentos ancestrais praticados por essas lideranças, vinculada principalmente à relação com a floresta, os sonhos e o mundo subterrâneo dos mortos. 
como designativo de "liderança espiritual", de "xamã", e de vẽnh péti ${ }^{5}$ e jãgti, para o plano "onírico".

Jorge Kagnãg Garcia, assim como Iracema Ga Rã Nascimento, kujà kaingang, respectivamente pertencendo à metade cosmológica Kamé e Kanheru-Kré, afirmam que antigamente as lideranças espirituais eram as mais respeitadas das aldeias (Maréchal, 2015; Rosa, 2005). Sendo guiados pelos seus jãgré (animais guias e/ou espíritos auxiliares), os kujà são grandes conhecedores da floresta e dos remédios que ela oferece. Em diálogos com Iracema, ela nos relata que os kujà são "escolhidos antes de nascer" e ingressam num longo e profundo processo de aprendizagem que os constitui. As crianças que não nasceram ainda recebem um dom, mas esse dom não garante porém que a pessoa será um(a) kujà, pois, o processo é árduo e envolve também dúvidas e receios por parte da pessoa. Os kujà, para se referir aos seus conhecimentos e saberes, usam as noções kujà kajrẽn e kujà jykré, que poderiam ser traduzidas de maneira rudimentar como "conhecimento dos kujà", no primeiro caso, e "modo de pensar e sentir dos kujà", no segundo. Os kujà kajrẽn remetem aos conhecimentos em si aprendidos e operacionalizados ao longo da vida do kujà, tais como: os sonhos, os remédios de ervas, as massagens, entre outros. Os kujà jykré se relacionam ao modo de pensar, de ser e de sentir que uma pessoa deve expressar para se tornar e se manter como kujà.

Levando em conta certa crítica ao uso do conceito "xamanismo", que não necessariamente toma em consideração situações coloniais (Balandier, 1951) e assim descontextualiza aspectos políticos e sociais de cada povo, evitamos cair numa generalização perigosa de saberes e práticas, que também são resultados

5 Essa categoria de sonho, segundo a kujà Iracema, remete a uma comunicação entre os/as kujà, com a finalidade de, juntos, encontrar soluções para, por exemplo, curar uma pessoa. Ver Maréchal $(2015,2018)$.

6 Os jãgti são os sonhos nos quais os kujà atravessam o plano terrestre para entrar no plano subterrâneo nũgme onde podem, por exemplo, ir a resgatar um kuprĩg (alma) que foi anteriormente capturado pela alma de um defunto que ficou com saudades. Ver Veiga (2000), Rosa (2005) e Maréchal (2015).

7 Momentos antes de uma viagem realizada pela kujà em companhia dos autores, em outubro de 2016, com o intuito de ela reencontrar seu umbigo, na TI Nonoai (ver Nascimento et al., 2017), foi relatado pela kujà aos autores memórias narradas a ela por sua mãe. Segundo a kujà, enquanto sua mãe ainda estava grávida dela, viu algumas cobras passarem por perto, o que ocasionou um susto naquele momento. Esse susto secou seus seios e, com receio de não dispor de leite materno, ela foi então consultar um dos kujà da aldeia. Ele lhe comentou que a aparição das cobras indicava que ela estaria grávida de uma criança com potencial para se tornar kujà. Além da informação, o kujà preparou um remédio de erva para que ela produzisse o leite para amamentar a criança que iria nascer. 
de processos históricos específicos. Contudo, deve-se ressaltar a eficácia do conceito enquanto ferramenta conceitual, pois permite abarcar um sistema relacional amplo que não se limita às práticas especificas dos kujà. Langdon (1996) retoma a história do conceito de xamanismo como vinculado à história da antropologia para avançar tal entendimento, sem necessariamente descartar toda uma produção vasta na disciplina. Assim, explicando o desenvolvimento do conceito de maneira a romper com uma assimilação de saberes e práticas de um universo religioso ou mágico, caracteriza que há uma necessária exposição do caráter sistêmico e amplo das práticas "xamânicas".

Chamar o xamanismo de um sistema cosmológico, e não de religião, evita algumas das antigas confusões [...] Falar de xamanismo em várias sociedades, implica em falar de política, de medicina, de organização social e de estética. (Langdon, 1996, p. 26-27).

Detalhando o que se entende pela nova perspectiva do conceito de xamanismo, encontram-se aspectos comuns na América do Sul. ${ }^{8}$ Entende-se aqui o xamanismo como uma práxis (Groisman, 1996), apoiada em uma cosmologia própria, porém dinâmica, e fundamentada por saberes ancestrais que também vão se reelaborando. O xamanismo deve ser considerado como produto de profundas dinâmicas históricas de fricção interétnica e resultado de processos de territorialização (Oliveira, 1998), que influenciaram, e seguem influenciando, transformando e ressignificando hoje essa práxis xamânica kaingang. ${ }^{9}$ Assim, entende-se aqui o xamanismo kaingang mais como uma capacidade relacional que se desenvolve a partir de múltiplas formas de conhecimentos, que os Kaingang vão descobrindo e experimentando, do que necessariamente um sistema fechado.

8 Entende-se o universo como composto de diversos níveis, onde a realidade visível sempre supõe outra invisível. A existência de um princípio geral de energia que unifica o universo. Um conceito êmico relacionado à existência de um "poder xamânico" a partir do qual o xamã consegue exercer forças nos domínios humanos e "extra-humanos". Um princípio de transformação. A eterna possibilidade de as entidades do universo se transformarem em outras. O xamã como mediador, que age principalmente em benefício do seu povo. As experiências "extáticas" que podem dar-se a partir de substâncias como tabaco, plantas psicoativas como também a partir de sonhos, danças e cantos (Langdon, 1996, p. 27-28).

9 Rosa (2005) estudou o xamanismo kaingang a partir da análise do que chamou de sistema kujà e o sistema caboclo, o segundo apontando à apropriação kaingang acerca da visão de mundo judaico-cristã. 
A capacidade de transpassar mundos implica também a existência de um universo sem divisões categóricas entre mundos, sendo todos eles permeáveis e em constante relação. Os mundos invisíveis tanto quanto o mundo dos fóg (brancos) compõem o território kaingang.

Os estudos sobre os sistemas xamânicos kaingang são numerosos e merecem certamente nossa atenção (Crépeau, 1994, 2000; Rosa, 2005, 2011, 2014; Silva, 2002, 2014; Veiga, 2000), porém busca-se neste trabalho entender a prática xamânica kaingang e especificamente os sonhos vẽnh péti na sua dimensão política e no seu potencial decolonizador de maneira situada, seja a partir dos mitos, seja a partir de acontecimentos que visaram resistência ao projeto colonial, ou mesmo ambos. Pretendemos ressaltar a necessidade de usar os conceitos êmicos kaingang, para apoiar essa proposta decolonial, ressaltando assim a prática xamânica kaingang na sua especificidade, historicidade e cientificidade. Buscamos entender o xamanismo kaingang em relação aos universos políticos, econômicos e sociais que o atravessam e pelos quais ele é atravessado. Dessa maneira, o xamanismo kaingang deve ser entendido antes de tudo como implicado em processos históricos atravessados pelo que Aníbal Quijano (2000) tem chamado de colonialidade do poder. ${ }^{10}$ Esses processos coloniais, históricos e contemporâneos, em todos seus efeitos e continuidades, na mesma medida em que atuam como forças capazes de destruir o tecido social kaingang provocam reelaborações e transformações nas cosmologias e organização sociopolítica dos próprios Kaingang. Resistindo a tais processos fortalecem seu povo, justamente a partir da reelaboração e criação de "novas" narrativas e mitologias que podem chegar a trazer o tom da resistência à colonialidade, fortalecendo assim sua luta por existir, através de uma "nova" memória guerreira, produto dos efeitos de tais processos coloniais.

10 Essa categoria refere-se à matriz estrutural de poder específica da modernidade, originada a partir da colonização da América no século XVI, e consequentemente à hegemonia global europeia. A colonialidade se compõe historicamente a partir da associação entre um novo sistema de dominação baseado em uma trama de relações sociais intersubjetivas que classifica hierarquicamente a população mundial, e um sistema de exploração que consiste na articulação de todas as formas de expropriação do trabalho em uma única estrutura de produção mercantil hegemonizada pelo capitalismo. Nesse sentido, a colonialidade é um dos elementos constitutivos do padrão de poder capitalista. A associação estrutural entre esses dois sistemas articula as classificações sociais baseadas nas ideias de raça, gênero e classe como novas identidades geoculturais globais com o novo sistema mundial de controle do trabalho (Quintero, 2010). 
Assim, no decorrer deste artigo abordaremos alguns exemplos etnográficos que provocam o leitor a pensar o xamanismo kaingang como uma ferramenta (cosmo)política, que pode se transformar em outro motor da luta pela terra e pela vida. Além disso, os exemplos aqui levantados ressaltam o uso da práxis xamânica kaingang além de sua expressão simbólica e/ou sua descrição cosmológica, mas notadamente no papel dos sonhos, vẽnh péti, como uma possibilidade decolonial implicada no presente e no passado, e voltada para um futuro.

\section{"A onça que pega o sol": um alerta sobre o fim do mundo}

Um exemplo da dinâmica da cosmologia kaingang encontra-se no testemunho da kujà Iracema Ga Rã Nascimento que relata a origem dos eclipses para os Kaingang. Os eclipses são explicados pela intervenção do mĩg (onça), que, triste pelo avanço da civilização e da destruição de nãn (a mata) e de ga (a terra) pelos fóg, encontra na fusão da humanidade a partir da escuridão a única saída possível; nas palavras da kujà:

Um dia estava em Nonoai, nos jogos, era umas dez da manhã, e estávamos brincando fora quando vimos garras se aproximando do sol. Eram as garras do mĩg, da nossa onça. O mĩg se aproximou bem perto do sol, nós todos vimos ele se aproximar, e ele o capturou. Ele capturou o sol e ficamos todos na escuridão. Daí nós, as mulheres, acendemos um fogo no chão, e os troncos velhos, os nossos antigos, pediram aos Kaingang da marca comprida, aos Kamé, para pegar seus arcos e flechas, pediram para eles acenderem a ponta da flecha no fogo e atirar do lado do sol que tinha desaparecido. Ao mesmo tempo, chamaram todas as mulheres e as crianças para dançar com os chocalhos, para que o mĩg devolvesse o sol, senão nós iríamos ficar na escuridão para sempre. Foi somente quatro horas mais tarde que ele reapareceu. Nós conhecemos essa lenda em kaingang dos nossos avós, eles contavam assim: "mĩg tá rõn mõny kã koreg ty nín kã eng ãh endo tá ty tu pé nu ty".11

11 Iracema nos informa que a tradução mais apropriada seria: “Essa lenda é conhecimento dos Kaingang que os fóg chamam de eclipse, seria um desastre para o ser humano, por isso que os Kaingang fazem de tudo para não acontecer." 
Quando perguntamos a Iracema por que a onça capturou o sol, ela nos afirmou:

Por causa da injustiça. Quer dizer, porque o sol é quem ilumina os dias, é ele quem mostra as riquezas da terra, como os minerais. Ele [o mĩg] está vendo que os fóg estão tirando tudo da terra e destruindo tudo, e ele quer impedir isso. Mas, se ele não devolvesse o sol, então iríamos todos ser extintos, por isso que os guerreiros Kamé tiveram que atirar a flecha de fogo do lado do sol, para o mĩg soltá-lo. Eu sei que os fóg chamam isso de "eclipse", mas para nós, cada vez que acontece, é porque o tigre pula e pega o sol. Ele faz isso porque está triste, por causa de todas as injustiças, por causa que nossa terra, $g a$, está sendo destruída.

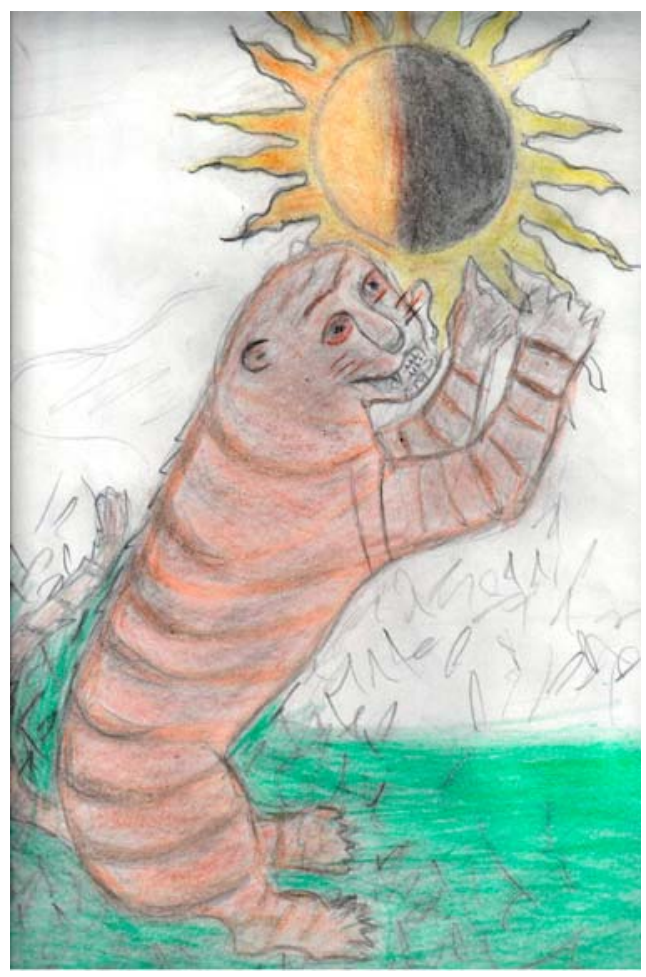

Figura 1. O mĩg pegando o sol (desenho de Kapri, filha de João e Iracema, fevereiro de 2017).

A história da onça que pega o sol aqui relatada expressa a exploração sobre ga (a terra), pelos fóg, segundo os Kaingang. O mito tem sentido situado, ele é produzido a partir da relação de dominação que se estabelece entre os destruidores da terra e o povo kaingang. Os mitos para os povos indígenas poderiam, erroneamente, ser lidos como formas desinteressadas de pensamento. Assim como os produtos da reflexão do filósofo e do cientista no Ocidente, os mitos para os povos indígenas são em verdade "um desejo de compreender o mundo que os envolve, a sua natureza e a sociedade em que vivem" (Lévi-Strauss, 2007, p. 28). Mas não esqueçamos que um dos problemas levantados por Lévi-Strauss estaria em compreender onde afinal acabaria o mito e começaria a história, 
pois sua preocupação decorre em situar a parte concernente à estrutura: básica e sempre a mesma (sistema fechado), daquela elencada como conteúdo: densa e podendo variar (sistema aberto). De fato, a reflexão sobre o problema levantado não é simples, ou passível de solução imediata. Para o que se pretende, a reflexão lévi-straussiana possibilita desestabilizarmos o que seja mito/história, considerando essas categorias como um registro possível de correspondência entre diferentes relatos. Nossa objeção é utilizar essas categorias de maneira mecânica, somente, como força de pensamento, ou seja, algo que exprimiria um duplo centro de gravidade da vida interior, na fórmula do homo duplex durkheimiano. No nosso entendimento os mitos possuem correspondência com a história, mas para além da representação da vida. Afinal, como Clastres (2014, p. 202) já teria apontado:

[...] os mitos constituem o discurso da sociedade primitiva sobre si mesma, eles envolvem uma dimensão sociopolítica que a análise estrutural evita, naturalmente, levar em conta, sob pena de entrar em pane.

O mĩg aparece como o ser que ressalta essa relação de exploração de ga, estando disposto a provocar o fim da humanidade para salvar ga. O povo kaingang aparece no mito como mediador entre o mĩg e os fóg, salvando a humanidade da escuridão provocada pelo mĩg. Porém, o mito gera aqui uma profunda crítica ao extrativismo e à exploração da terra em prol de uma fábula capitalista, onde os seres da terra são negados e/ou exterminados pelos fóg, ${ }^{12}$ ou seja, vivifica e situa contextualmente uma historicidade relacional e colonial, a partir da cosmologia kaingang. Como ressalta Quintero (2015b, p. 256), os mitos estão enraizados em imaginários sociais e na memória histórica das pessoas que os (re)produzem. A origem do eclipse kaingang, o sol sendo capturado pela onça, é uma expressão profunda de relações de poder e dominação, mas também reflete as possibilidades de transformação do mundo, possibilidades agenciadas tanto pelos seres extra-humanos (a onça) quanto pelos Kaingang, que, nesse caso, são os que decidem fazer emergir o sol outra vez.

Ao mesmo tempo em que os mitos ressaltam relações de dominação e subordinação inscritas na história, nas feridas coloniais (Anzaldúa, 1987)

12 Para um caso similar com os Yanomami, ver Albert (1995). 
e na colonialidade, também apresentam possibilidades de transformação do mundo a partir da subversão e da resistência, inscritas, também, na memória.

\section{A primeira kujà}

Foi do pai do mato, Kakawej, que nasceu a primeira kujà kaingang. Kakawej é uma árvore de tronco largo e grosso, seus ramos são da cor da terra e suas folhas são verdes profundo. Ele tem flores alaranjadas e amarelas que crescem do lado onde o sol nasce, e flores azuis, elas são mais escuras e crescem do lado onde o sol foge, do lado de onde a lua nasce. Kakawej é uma árvore que cresce somente no meio do mato fechado, sempre rodeado por fág, a araucária, mũ, a jabuticaba, e pẽnva, a guabiroba. Numa noite estrelada, os bichinhos todos começaram a gritar e nossos antepassados acordaram e chegaram até Kakawej, onde contemplaram, sem palavras, o nascimento da primeira kujà. De Kakawej, nasceu uma mulher com a pele da cor da terra e com o cabelo preto do tamanho do seu corpo. Como era de noite, todos os animais estavam na volta da árvore, as flores laranja e azuis brilhavam, os pássaros se deslizavam debaixo dos seus ramos respeitados por todos os animais. "Ka ta fi fy nhã", "a árvore está chorando por ela", dizem nossos antepassados, porque das folhas de Kakawej cai a chuva que benze todos os seres.

A mulher saiu de Kakawej, ficou parada um tempo do lado do sol e conversou com o tigre, mĩg, com o leão baio, jakũnh, com os pássaros, jẽsĩ, logo circulou do lado onde o sol foge e conversou com os outros animais, com a pantera, o pica-pau e as abelhas. Depois ela passou atrás de Kakawej e na sua frente. Ela fez um círculo, o mesmo círculo que hoje nós fazemos nas nossas danças. Nenhum dos nossos antepassados precisou falar com ela, era seu corpo quem falava. Os nossos antepassados ficaram olhando para ela em silêncio até ela sumir no meio do mato.

Umas duas semanas depois, uma mulher kaingang, uma das minhas antepassadas, sonhou e acordou desesperadamente do lado do seu marido. No sonho, a mulher que saiu de Kakawej estava chamando ela em cima do rio: "Vem!" A kujà estava com os remédios de ervas vẽnh-kagta na mão na beira do rio convidando a mulher a chegar perto dela. $\mathrm{O}$ marido foi junto com sua esposa até o rio e encontraram a kujà de cabelo preto e comprido, sem um pelo no corpo. A kujà mostrou o remédio vẽnh-kagta para o casal, e sem dizer uma palavra, esmagou na sua mão a folha, jogou sua mão na água e somente com seus gestos ela ensinou a mulher 
a tomar banho de ervas. Mostrou para a mulher três folhas que somente ela poderia usar, apontou com o dedo para três bichos: o leão, o tigre e a águia, eles três iam ser seus jãgré. Após isso, ela bateu três vezes as palmas e olhou para o marido da mulher indicando para ele que era hora dele ir embora. A mulher estava se tornando uma kujà e nunca mais poderia ter marido. ${ }^{13}$

Até há pouco tempo, Kakawej existia em Nonoai, foi nessa árvore que meu avô me levava. Kakawej tem, dentro dele, um buraco, esse é o buraco de onde saiu nossa primeira kujà. Nesse buraco é onde nós tratávamos os nossos parentes atingidos por doenças terríveis. (Relato de Iracema Ga Rã Nascimento, contando a história que seus avós contaram para ela. Fevereiro de 2017).

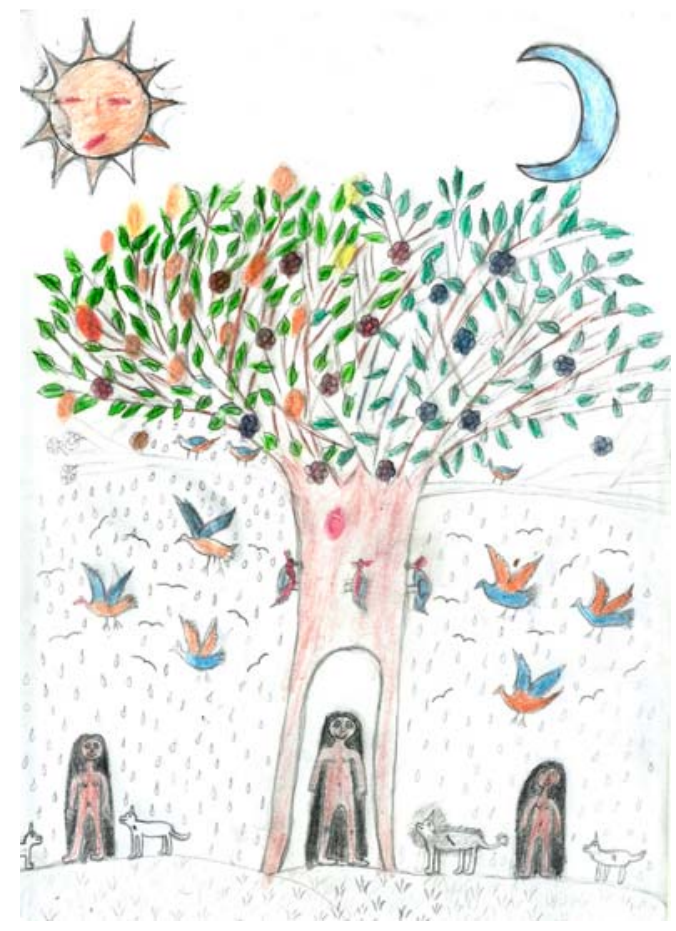

Figura 2. A primeira kujá. (desenho de Carolaine Carvalho, sobrinha de Iracema, fevereiro de 2017).

O desenho da "primeira $k u j a{ }^{\prime 14}$ e o relato de Iracema fazem referência ao nascimento do "xamanismo" kaingang. Os primeiros ensinamentos são

13 Rosa (2011), a partir da sua etnografia com os/as kujà kaingang, indica que alguns jãgré podem ser muitos ciumentos em relação a seus kujà e não deixar eles se casarem nem ter filhos. Chamados de "guias de ferro", esses jãgré ressaltam a expressão de um casamento mítico entre o/a kujà e seu/sua parceiro/a xamânico/a.

14 Iracema indicou cada detalhe para sua sobrinha colocar no papel esse relato mítico, ela prestou uma atenção particular à pertença de cada ser que habita o mundo à sua metade cosmológica. Vejam-se a cor das frutas e as características dos animais. Porém, enquanto à primeira kujà, ela não assumiu nenhuma pertença a uma metade cosmológica em particular. Em outros relatos e outras etnografias (Maréchal, 2015; Rosa, 2005), autores afirmam que os kujà, $\rightarrow$ 
protagonizados por duas mulheres, a primeira kujà que se torna presente na vida cotidiana kaingang manifestando-se no sonho de outra mulher, que aceitará receber os conhecimentos e assim se tornará kujà de uma comunidade. Ressaltam-se dois elementos que são do interesse deste artigo no relato de Iracema. O primeiro é a importância dos sonhos na construção e na prática do xamanismo kaingang e o segundo é o protagonismo feminino no nascimento do xamanismo kaingang. Os sonhos, vẽnh péti, são elementos fundamentais para a prática xamânica kaingang, eles são meios de comunicação entre o mundo visível (o mundo aqui) e mundos invisíveis onde os kujà se encontram para resolver problemas relacionados ao mundo aqui. No relato mítico de Iracema, o surgimento e a expansão do xamanismo kaingang é possibilitado por um sonho que conecta duas mulheres. Assim, os sonhos e as mulheres aparecem como os dois elementos fundadores do xamanismo kaingang.

Existem várias palavras para definir os sonhos, pois são sonhos com caráter diferentes. Cada sonho precisa ser contextualizado. A contextualização no mundo kaingang permite entender complexidades cosmológicas que relacionam os sonhos com mundos diversos. Iracema, kujà kaingang, mentora intelectual do desenho da primeira kujà, relata que os sonhos que se tem para matar saudades dos falecidos são chamados de nũgme jãgti. Esses sonhos implicam uma transportação da pessoa que sonha ao mundo maravilhoso e perigoso do nũgme. Iracema define o nũgme como uma aldeia onde todos os parentes que morreram vão descansar. No momento da morte, o vẽnh kuprĩg (espírito) se desprende do corpo e voa até a aldeia dos mortos, no mundo subterrâneo. ${ }^{15}$ Porém, algumas pessoas são condenadas a vagar eternamente pelo mundo dos vivos como, por exemplo, aquelas pessoas que cometeram suicídio. Os kujà têm o poder de conversar com aquelas pessoas que estão no nũgme, pois é através

$\rightarrow$ ao se tornarem kujà, através de um rito de passagem no qual agrega-se ao seu nome outro nome composto por elementos pertencendo às duas metades cosmológicas, passam a assumir também a outra metade cosmológica. Assim, os kujà possuem dois nomes: um nome associado à linhagem paterna e então cosmológica e um nome de kujà, que ressalta a incorporação dentro de uma mesma pessoa das duas potencialidades cosmológicas: Kamé e Kanheru-Kré. A origem da metade cosmológica da primeira kujà fica então um ponto a esclarecer por pesquisadores interessados, pois poderia nos ajudar a entender a importância das metades respectivas na origem do xamanismo kaingang.

15 Segundo os Kaingang, o universo está dividido entre três planos: kaika, o ceú, o lugar habitado por Tupã; $g a$, a terra, onde todos nós habitamos; e o nũgme, o mundo subterrâneo, onde habitam os defuntos (Crépeau, 2006; Rosa, 2005). 
desses sonhos que os kujà podem se comunicar com os antepassados como também salvar pessoas cujo vẽnh kuprĩg foi capturado pelos espíritos dos mortos, com saudades dos vivos. ${ }^{16}$

Uma outra modalidade de sonho é chamada por Iracema de vẽnh péti. ${ }^{17}$ Nesses sonhos, os kujà conseguem se comunicar entre si e com seus imprescindíveis parceiros, os jãgré que costumam guiar-lhes nessas viagens que eles percorrem nos mundos invisíveis. O mundo "visível" é chamado de inh ga kri, que, literalmente, significa "acima da minha ${ }^{18}$ terra", e o mundo dos sonhos, "invisível", é chamado por Iracema de inh ga kri vẽnh péti, que, literalmente, significaria "os sonhos acima da minha terra". O plano terrestre ga não muda de nome enquanto, sim, mudamos de mundos. Dentro de ga, existem vários mundos visíveis e invisíveis e somente os kujà têm a capacidade através, por exemplo, dos sonhos, para transpassá-los. Os kujà também têm o poder de atravessar os diferentes planos do universo kaingang. Os sonhos são assim uma maneira de transpassar diversos mundos que pertencem a um mesmo plano ou de atravessar os diversos planos, mas se inscrevem, porém, dentro do mesmo território/universo kaingang.

\section{Sonhos e cosmopolítica kaingang}

Os estudos etnológicos sobre os Kaingang destacam a proeminência dos sonhos em sua composição para "ver o futuro". Comunicando-se com outros kujà, com seus jãgré ou com seus antepassados, os kujà, através dos seus sonhos, buscam conter e/ou transformar perigos possíveis encontrados nas suas visões

16 Para uma etnografia mais detalhada sobre o mundo dos mortos ver Rosa (2005, p. 372-376).

17 Iracema relata que a palavra difere segundo o dialeto. Em Nonoai, os Kaingang os chamam de vẽnh péti, enquanto no Paraná, de jãkti. Quando pedimos a Kókaj (Selvino Amaral, professor bilíngue kaingang) ajuda para a ortografia desse termo, ele nos informou que o termo jãkti remeteria à ação de "sonhar com", enquanto o conceito vẽnh péti significaria "sonho". Uns meses depois, Iracema mencionou também a palavra jãkti, mas em um contexto diferente, se referindo a sonhos que transpassam o plano terrestre até o mundo subterrâneo, nũgme.

18 O termo inh é traduzido como "eu, minha, meu", porém Carvalho (2011, p. 173) o traduz como "pessoa", que seria composta por quatro elementos: as metades, o jiji (nome), hã (corpo) e o kumbá (espírito do corpo). Nesse sentido, ressalta que inh não poderia ser simplesmente assimilado ao "eu" em português, pois leva consigo uma dimensão cosmológica que é necessário compreender. 
oníricas. Essa prática xamânica específica dos conhecimentos dos kujà (kujà kajrẽn) expressa uma relacionalidade entre visível-onírico, passado-presente-futuro, mortos-vivos, humanos-extra-humanos, categorias que, desde o olhar moderno-colonial, estariam notadamente separadas (Fernandes, 2003; Hermann, 2016; Maréchal, 2015; Rosa 2005). Esse papel destacado do inh ga kri vẽnh péti (domínio onírico, mundo dos sonhos) e das práticas dos kujà para o plano visível (inh ga kri) seriam fatores articuladores de eventos na vida kaingang.

Seguindo tais compreensões seria possível introduzir, preliminarmente, que os sonhos tanto não estariam apartados do plano visível quanto colaborariam em sentido ampliado como expressão cosmopolítica ${ }^{19}$ kaingang em sua contraposição à "política", no sentido moderno-colonial, como uma relação histórica de dominação onde os povos acabariam sendo subjugados aos interesses dos governantes: após passar por mais de um século submetidos às hierarquias militares, os Kaingang foram incorporando modalidades de organização social, refletindo a perversão e profundidade da colonialidade do poder. ${ }^{20}$ Atualmente, são "recebidos" dentro dos espaços dos representantes do Estado de maneira similar, pois ainda se impõe aos indígenas no Brasil a necessidade de criar seus próprios representantes, ou seja, pessoas especializadas para dialogar com as autoridades do Estado. Os representantes indígenas tiveram que aprender a manejar a linguagem dos fóg para sobreviver. Porém, ao mesmo tempo em que a linguagem política dos fóg foi (e está sendo) aprendida, incorporada pelos Kaingang, suas formas próprias de "fazer política" vêm se combinando com as aprendidas e assim construindo uma cosmopolítica que, por se compor dinamicamente com diversas forças, pode chegar a se tornar mais potente. Não faltam dados etnográficos que demonstram a relação direta entre os sonhos, sejam eles os vẽnh péti e/ou jãgti, e seus efeitos sobre as reivindicações políticas e territoriais kaingang.

Aquino (2008) narra vários episódios de sonhos que uma de suas interlocutoras, a kujà Nimpre, tivera nos anos 2000 enquanto residia na região litorânea

19 Sobre cosmopolítica ver Stengers (2005).

20 No caso do povo kaingang a ferida colonial em relação à sua militarização é muito marcante. Seja em relação aos castigos usados nas Terras Indígenas (como o chamado de tronco, ou as cadeias), seja em relação aos cargos militares que os Kaingang ainda atribuem às suas lideranças (capitão, coronel, soldados); ver Valente (2017). 
do Rio Grande do Sul. Nimpre sonhou com um kujà que havia morrido em uma guerra entre índios e brancos. Segundo o autor, ela teria recebido uma mensagem importante desse kujà que afirmava que existia, em algum lugar da região litorânea - aí descrita incluindo Porto Alegre -, uma terra ancestral, relatando que somente descansaria quando os Kaingang retomassem aquela terra para si. Pouco tempo depois Nimpre verificou que seria o Morro do Osso, na qual Kentanh, uma liderança kaingang da região, já havia iniciado a articulação política para (re)tomada do espaço que se tornou a aldeia Tupã Pen (Pé de Tupã).

Foi através dos sonhos e "visões" de Nimpre e dos "conselhos" de Kentanh (juntamente com outras lideranças de sua "marca" ou de outra "marca", como Rokã e Xê, respectivamente), do índio curado pelo “Tupë pën”, e de modo geral das relações que as mulheres e os homens kaingang que constituíram a aldeia estabeleceram com o cemitério, os mortos, e os diversos Outros (como os fóg, os Guarani, os [espíritos de] animais e plantas, pedras, "cemitério indígena", etc.) implicados no lugar, que os Kaingang fundaram ga mág em uma área nesse processo definida como uma terra ancestral (ga sí), focalizando a constituição do coletivo (kanhgág kar). (Aquino, 2008, p. 77).

Como afirma Rosa (2005), em seu estudo sobre o sistema xamânico kaingang, mesmo Horta Barbosa ${ }^{21}$ não tendo acreditado na existência de um Kaingang que concentrasse em si as atribuições de um "pajé guarani", ele teria notado a importância e o poder do plano onírico entre algumas mulheres kaingang:

Os Caingangue acreditam que algumas mulheres têm o dom de adivinhar o futuro, vendo claramente durante o sono o que sucederá em projetadas expedições e caçadas. Acreditam mais que esses sonhos proféticos podem ser provocados, bastando para isto ingerir a sonhadora, um pó tenuíssimo, que se obtém pilando folhas de certo vegetal. Mas conquanto os homens não se dispensem de consultar esses oráculos na véspera de iniciarem novas empresas, contudo não desistem de as levar por diante, ainda que a resposta lhe seja desfavorável;

21 Luiz Bueno Horta Barbosa era inspetor do (extinto) Serviço de Proteção ao Índio (SPI) em São Paulo no início do século XX, quando da "pacificação" dos Kaingang por aquele órgão, conforme material publicado em 1947. 
é evidente, porém, que neste caso a ação se ressente da falta de firmeza e de pertinácia, necessárias para garantir-lhes o bom êxito. (Barbosa, 1947, p. 65 apud Rosa, 2005, p. 111).

Fernandes (2003) teria notado que desde os observadores e comentaristas sobre os Kaingang, no final do século XIX e início do século XX, haveria uma associação entre poderes "religiosos" e "políticos", pois:

[...] o próprio Telêmaco Borba afirmava que os chefes empregavam conhecimentos provenientes de sonhos para predizer bons ou maus tempos; conhecimentos estes que eram trocados pela lealdade de seus subditos. O comentário de Borba não é um comentário isolado, afinal, os Kaingang dispõem de uma categoria que define ao mesmo tempo autoridade política e autoridade religiosa: paí ou põ̃i. (Fernandes, 2003, p. 148). ${ }^{22}$

Os sonhos, conforme teria afirmado Jorge Kagnãg Garcia, um kujà kaingang, a Rosa (2005), são item fundamental no desenvolvimento da relação deste com seu guia/espírito auxiliar (jãgré), de conexão com a experiência empírica invisível, aquilo que se refere à transmissão de conhecimento e poder de um determinado espírito animal à pessoa responsável pela mediação entre o "mundo-aqui" e o "mundo outro". Nesses sonhos os jãgré cederiam ao kujà a capacidade de "olhar" para o futuro, saber o nome daquele que teria enviado um feitiço, por exemplo. Rosa (2005) explicitou que os sonhos comporiam de forma conjunta outros elementos que formariam o sistema kujà e o sistema caboclo: o uso de espíritos-auxiliares, de remédio do mato, de altarezinhos, e de novenas. Em nota de rodapé o autor esclarece para quais objetivos e como poderiam se articular tais elementos:

22 Fernandes ressalta o poder do p’oi como liderança político-espiritual, enquanto para os nossos interlocutores Iracema Nascimento e Jorge Garcia, é ao "cargo" de kujà que está associada a liderança política. Para Fernandes, o político engloba o espiritual materializando-se no conceito de p'oi, enquanto para Jorge Garcia e Iracema Nascimento, o aspecto político do p'oi está sendo englobado pelo "espiritual", materializado no conceito de kujà. Nos dois casos, o nosso argumento procura ressaltar a existência de uma interdependência e interligação entre os cargos políticos e espirituais associados às respectivas lideranças. Antigamente, tanto os p'oi quanto os kujà assumiam funções político-espirituais, já que os dois domínios não deveriam ser apreendidos por separado mas formando parte de um mesmo sistema cosmológico. 
Por sua vez, o ex-kujà Jorge Kagnãg Garcia disse-me durante a conversa em sua nova casa na T.I. Serrinha, que era através de sonhos, na "floresta virgem", que ele conversava com seu jagrẽ tigre, desse domínio, partia para o "nũgme" para trazer consigo o kuprĩg da pessoa doente: "quando começava a sonhar estava lá". (Rosa, 2005, p. 373).

Nesse sentido, vários estudos etnológicos destacam os sonhos vẽnh péti como um dos elementos potentes na relação cosmopolítica kaingang com os atravessamentos do vivido e outras formas de litígios realizados em diversos domínios, incluindo o domínio da cidade, das instituições e seus dispositivos de governo. Essas leituras demonstram que os sonhos são motores de luta pela terra e vida; através do seu poder de cura, de "visão" e de conexão com seres de outros mundos, esses saberes são fontes de resistência à colonialidade, e, se compondo com outros saberes, como por exemplo as demandas por direitos à terra, educação e saúde, eles conformam o que podemos chamar de cosmopolítica kaingang. Porém, podemos nos perguntar se além de serem componentes de uma cosmopolítica kaingang e motores de resistência, eles poderiam se transformar em potencialidades decolonializadoras, e se for o caso como poderia ser feita essa passagem? Trazemos aqui novamente reflexões de uma respeitada liderança indígena para nos incitar a pensar o xamanismo kaingang como não somente um componente da cosmopolítica kaingang, mas também como fonte de possíveis horizontes decoloniais.

Numa palestra na Universidade Federal do Rio Grande do Sul em novembro de 2015,23 Ailton Krenak (2015, p. 332), liderança indígena conhecida mundialmente, mostrou preocupação em relação aos processos de recolonização dos quais os indígenas fazem parte, quase sem se dar conta, levando os "cacoetes coloniais que ficamos repetindo como uma criança repete o gesto da mãe ou do pai". Tomou como exemplo a proposta de política educativa do ex-ministro da Educação Cristovam Buarque, que na época queria "acabar em cinco anos com o analfabetismo no Brasil”. Embora Ailton tivesse muita admiração pelo ex-ministro da Educação, indignou-se diante de tal proposta, segundo ele, colonizadora:

23 Palestra conferida em evento promovido pela rede de pesquisa Abya Yala: Epistemologias Ameríndias em Rede, no auditório do Instituto Latino-Americano de Estudos Avançados (Ilea), Campus do Vale, Universidade Federal do Rio Grande do Sul, na tarde do dia 6 de novembro de 2015. 
Eu olhei e falei: “Como é que um cara genial como o Cristóvão Buarque pode falar uma besteira tão alarmante?" Porque se você pensa esse país nosso fazendo uma campanha para não deixar ninguém sem a prática da escrita e da leitura, significa que você vai colonizar os últimos redutos de memória decente que ainda não foi invadido pela palhaçada colonial que domina todo o mundo, desde a religião até o consumo do último biscoitinho do mercado. (Krenak, 2015, p. 342).

O conceito de cosmopolítica nos ajuda a entender a política indígena (e kaingang nesse caso) como composta por diversas ferramentas, elaboradas e reelaboradas nos processos coloniais históricos e contemporâneos e incluindo a práxis xamânica como parte dessa "política", mas não chega a abranger os desejos de ruptura com o sistema moderno-colonial-capitalista suposta pela decolonialidade. A proposta cosmopolítica se limita a uma tentativa de simetrizar conhecimentos buscando colocar na mesma escala de valor os conhecimentos tradicionais e os saberes ligados à modernidade. Porém, os estudos sobre colonialidade (Quijano, 2000) nos ajudam a visualizar que uma simetrização real dos conhecimentos somente se torna possível no movimento preliminar de desprendimento do Ocidente (Mignolo, 2007). Esse desprendimento não exclui uma possível "composição" e complementariedade entre saberes tradicionais e ocidentais, porém implica uma valorização tanto dos saberes e conhecimentos que fogem do pensamento moderno-colonial e que escapam ao movimento de recolonização ${ }^{24}$ quanto do próprio movimento, da própria vontade de fuga. Impulsionar processos decoloniais ${ }^{25}$ passa então por uma necessária ruptura com a modernidade. Trata-se mais de um movimento inicial de "desaprendizagem" de tudo que fomos forçados a incorporar e da desconstrução de uma matriz colonial interiorizada ${ }^{26}$ do que uma composição simétrica de múltiplos saberes.

24 “Recolonizar é botar para dentro uma demanda que não é nossa, exportar nossa água e o nosso solo, criar pobreza nesses lugares, não dar oportunidade para essas pessoas se estabelecerem com dignidade [...] Roubar o futuro dos nossos filhos e dos nossos netos é conviver com a possibilidade dos nossos rios virarem esgotos" (Krenak, 2015, p. 334-339).

25 Exemplos de encaminhamentos de processos decoloniais podem ser encontrados na compilação de artigos sobre alternativas decoloniais ao capitalismo colonial-moderno em Quintero (2015a).

26 Enquanto o colonialismo se refere a uma relação de poder exercida por um povo sobre outro, a colonialidade indica a perduração e a reprodução no tempo dos efeitos criados pela ação colonial. (Quijano, 2000). 
Assim, a cosmopolítica não se enfrenta diretamente com a colonialidade do poder em todas suas dimensões, já que a lógica do poder encontra-se presente principalmente na subjetividade. Sem o desmantelamento da colonialidade do poder, a cosmopolítica só é capaz de fazer arranhões ao poder.

Voltando à dúvida e crítica de Krenak à proposta de Cristovam Buarque, ainda que bem intencionado, o ex-ministro da Educação, ao propor "alfabetização para todos", propunha também a universalização do saber, forçando assim todos os habitantes do Brasil a deixar de lado formas ancestrais de comunicação e relacionalidade. Além disso, a proposta supõe o saber ocidental-moderno como único horizonte futuro possível, reificando mais uma vez sua superioridade e hegemonia diante de outros saberes. Assim, como afirma Costa (2014, p. 930), "a descolonização do conhecimento não será possível se seu ponto de partida for o das categorias do saber ocidental".

O que compreendemos, trazendo a reflexão de Krenak (2015) lado a lado com as leituras que realizamos de etnografias sobre os Kaingang, é que horizontes decoloniais emergem, e podem emergir, desde o xamanismo kaingang, dos sonhos e das práticas que envolvem tais projetos. A crítica de Krenak (2015) é pertinente tanto para fazer visibilizar novos horizontes desde a perspectiva indígena quanto para tornar evidente a perpetuação da colonialidade nas propostas políticas vindas da esfera governamental (por mais preocupadas com a justiça social que estejam). ${ }^{27}$ Entendemos que os exemplos acima, e outros que detalharemos com maior profundidade na sequência deste artigo, demonstram a práxis xamânica kaingang tanto como compondo a cosmopolítica kaingang quanto como um possível impulso para movimentos decolonizadores.

\section{Da ferramenta cosmopolítica à possibilidade decolonializadora}

Hermann (2016, p. 77-103) detalha os acontecimentos, segundo a perspectiva de interlocutores kaingang, entre eles a kujà Iracema Nascimento, de procedimentos necessários para a abertura e permanência dos Kaingang no centro

27 Sobre decolonialidade e socialismo, ver Grosfoguel $(2007,2011)$. 
da cidade de Porto Alegre, em especial a participação kaingang na feira urbana chamada de Brique da Redenção. ${ }^{28}$ Na primeira metade da década de 2010 estava constituído um processo de negociação e proliferação de boatos no município, protagonizado por alguns membros da Associação dos Artesãos do Brique da Redenção (Aabre), que se contrapunha veementemente à presença kaingang na feira e na própria cidade. ${ }^{29}$

Tais boatos destacavam justamente argumentos sobre o que seria ou não legítimo para os "índios". Ainda havia nesse momento um projeto que visava ordenar o Brique da Redenção ${ }^{30}$ via a construção de uma estrutura arquitetônica, o que apontava para o conjunto de famílias kaingang "o fim do Brique". Iracema, preocupada já em 2012, vinha pensando em formas de conter tal projeto; nesse sentido reconstituiu para o antropólogo encontros realizados por ela e seu companheiro em reuniões junto a Secretaria Municipal de Indústria e Comércio (SMIC) anos antes. Iracema afirmou que a partir dos sonhos contornou as estratégias dos dirigentes da SMIC para impedir a presença de famílias indígenas em Porto Alegre.

Iracema demonstrou que pouco tempo após "que o tio Miro tomou o tiro do policial no Brique" ${ }^{31}$ participou de encontros e reuniões organizadas

28 Para mais detalhamentos, ver Hermann (2016, p. 45-102).

29 Zilio Jagtag Salvador, jamré de Iracema foi detido pelos guardas municipais quando coletava cipó para fazer o material da família em abril de 2007. A notícia foi publicada no jornal Diário Gaúcho em 19 de abril de 2007 trazendo a imagem de Zilio algemado e a chamada da capa: "Caingangues ficam sem matéria-prima."

30 Eram boatos sobre a construção de uma estrutura que contemplaria apenas os boxes dos artesãos não indígenas no Brique da Redenção. Em entrevista ao antropólogo Herbert W. Hermann em 2015, Luiz Fagundes, então assessor técnico da Secretaria Adjunta dos Povos Indígenas e Direitos Específicos (Sapide/SMDH), afirmou que participou de uma série de reuniões juntamente com outros indigenistas e servidores da prefeitura, algumas incluindo promotores do Ministério Público Federal, para versar sobre a comercialização do artesanato indígena. Um dos tópicos era o então projeto Monumenta, com recursos do Instituto do Patrimônio Histórico e Artístico Nacional (Iphan) para restauração de locais com valor histórico na cidade, e o total desconhecimento dos gerenciadores do projeto sobre a presença e as demandas kaingang naquela feira urbana.

31 O fato se refere ao disparo de tiros por parte de um soldado da Brigada Militar contra o então cacique da aldeia do Morro do Osso no Brique da Redenção, em 4 de novembro de 2007. A Fundação Nacional do Índio (Funai) moveu ação civil pública nº 2008.71.00.016340-8/RS contra o Estado do Rio Grande do Sul interpelando indenização por danos morais e materiais da comunidade indígena. 
pela SMIC que tratavam justamente sobre a venda dos produtos industrializados comercializados por parentes kaingang. Naquele momento, a acusação dos não indígenas era que os Kaingang "não seriam mais índios". Como o coletivo de Iracema comercializava principalmente "artesanato indígena", aos olhos dos agentes do Estado e demais atores sociais conquistar seu apoio atuaria como justificativa para expulsar as outras famílias kaingang da feira.

A partir dessas reuniões, teria se firmado um acordo verbal apenas entre a família de Iracema e os agentes do Estado, de que eles receberiam um box na nova estrutura a ser construída. Contudo, o acordo precisaria de trâmite público e ainda mereceria a formatação de um documento que expressaria seus termos. Nesse intervalo, entre o aceite da oferta e a assinatura de documentos, Iracema sonhou algumas vezes com seu falecido pai, Penĩ, que lhe alertou tanto sobre as intenções desses fóg, no "aprisionamento" de sua família dentro de um box, quanto sobre as complicações que adviriam futuramente com e para os parentes kaingang.

Iracema conta que sonhara com seu pai Penĩ, e que teria sido aconselhada por ele a não assinar qualquer documento envolvendo o Brique, assim como a dissuadir João, seu companheiro, sobre esse acordo. Iracema, segundo Hermann (2016), iniciaria uma conversa no domínio da casa com seu companheiro e uma série de esforços de coleta e preparação de banhos com vẽnh-kagta (remédio do mato) para manter comunicação com seu falecido pai, Penĩ. Para isso, ela procedera a coletas de vẽnh-kagta, indicadas por seu jãgré, no Morro Santana.

Os episódios em que os vẽnh péti (sonhos) atuariam decisivamente frente às ações da política dos fóg e suas estratégias sugerem a potência das relações cosmológicas em diversos domínios, que juntamente com outros conhecimentos dos kujà e suas práticas contêm o avanço do projeto colonial.

A negociata em tom de oferta possibilita visibilizar algumas estratégias políticas às quais os indígenas ainda necessitam se contrapor na atualidade: (1) que um representante político indígena poderia solucionar "problemas sociais"; e (2) as formas pelas quais tais dispositivos de governo acabam nutrindo ainda mais conflitos internos do que auxiliando o bem-estar e o bom viver entre coletividades indígenas.

Iracema, a partir da mediação dos sonhos, dos conselhos e conversas com o espírito do seu pai, dos banhos com vẽnh-kagta (remédio do mato) extraído em porções de mata na própria cidade de Porto Alegre, reestabelece modalidades 
de resistência que visam produzir efeitos coletivos não circunscritos a si, como, por exemplo, a união entre famílias kaingang, em que territórios-práticas xamânicas se entrelaçam, também envolvendo a cidade, os seres extra humanos, os espíritos dos falecidos, os sonhos e os fóg.

Maréchal (2015), por sua vez, narra acontecimentos, também com a participação da kujà Iracema, em um outro evento, no ano de 2014. A kujà teria iniciado várias ações após os sonhos com Marcolina, uma kujà com maior formação e considerada por ela como uma de suas mestras, que reside na TI Votouro, no que diz respeito a uma série de acontecimentos que precederam uma viagem que realizou na comunidade de Votouro/Kandóia, no planalto rio-grandense. Naquele momento, as pessoas na aldeia sofriam com a prisão de suas lideranças, efeito da persistente luta pela demarcação das suas terras. ${ }^{32}$

Primeiro foi o sonho com Marcolina, ela disse para mim que eu ia a sonhar com a mãe do cacique sem que eu soubesse que ia precisar de apoio, a kujà me contou pelo que estava passando. Ela pediu pra eu levar esses remédios, que pudesse usar para fortalecer ela e o seu filho e eu nem sabia quem que era o filho dela. Duas noites sonhei e sonhei que levaria o remédio para eu fazer o meu trabalho. (Relato de Iracema, cf. Maréchal, 2015, p. 129).

Iracema, após ter sonhado com sua mestra Marcolina, sonha outra vez, mas que iria entregar para sua jamré, Madalena de Paula - mãe do então cacique da comunidade de Kandóia que estava preso na prisão do Jacuí - um remédio de ervas para fortalecê-la e apoiar a comunidade. ${ }^{33}$ Como observa Rosa (2005, p. 336), Madalena de Paula trata-se também de uma kujà. Após ter sido guiada pelo seu jãgré, o mĩg, para escolher o remédio no Morro Santana em Porto Alegre, Iracema iria ao encontro de Madalena de Paula em Kandóia, para lhe entregar o remédio. Ao todo faria duas viagens até Kandóia, que tinham por objetivo fortalecer a comunidade através da sua práxis xamânica. $\mathrm{O}$ encontro onírico entre as três kujà, Marcolina de metade cosmológica Kamé, Madalena de Paula, que também pertence à metade cosmológica Kamé, e Iracema Nascimento,

32 Para mais detalhamentos, ver Maréchal (2015, p. 114-160).

33 Sobre os acontecimentos em Kandóia e a criminalização das lideranças kaingang, ver Comunidade Kandóia/Votouro (2014). 
que pertence à metade cosmológica Kanheru-Kré, ${ }^{34}$ torna visível a potencialidade política do xamanismo kaingang em momentos nos quais os Kaingang acabam sendo "vencidos" no terreno da política moderno-colonial. Por escapar e se contrapor à racionalidade moderna, o xamanismo aparece aqui como uma potência que, ao ser desenvolvida e fortalecida através da "aceitação" das pessoas em Kandóia, oferece novos horizontes decoloniais possíveis. Além de devolver o caráter político à práxis xamânica, a experiência de Iracema também devolve ao protagonismo feminino kaingang sua força (cosmo)política. Nos sonhos e nas viagens a Kandóia são as mulheres que receberam e relataram o sofrimento da comunidade a Iracema, que, no seu papel de mediadora, iria expor a situação além de Kandóia, em sua volta a Porto Alegre, buscando falar todas as verdades que a imprensa se empenhava em esconder sobre os acontecimentos. Segundo Iracema, sua mestra Marcolina realizou o trabalho de avisar as mulheres de Kandóia anteriormente de sua chegada "física" à comunidade, por isso, todas elas estavam preparadas para o encontro:

Elas estavam prontas pra chegar pessoas. As mulheres todas tinham tomado banho. A kujà Marcolina é avó dela [de Madalena]. No sonho, ela também sonhou com a sua kujà. A mãe do cacique tinha ido lá no Votouro dois dias antes e a kujà [Marcolina] já tinha falado que ia chegar essa pessoa [a própria Iracema], sua jamré. Tinha falado que ia vir gente de longe, não de Nonoai, não de Carazinho, mas de mais de 400 quilômetros. "É a tua jamré", falou, "e ela vai trazer remédio para queimar e cuidar do teu filho." Ela já ficou esperando pessoas chegarem. (Relato de Iracema, cf. Maréchal, 2015, p. 137).

O trabalho conjunto xamânico das três kujà, assim como a colaboração das outras mulheres da comunidade, expressam uma profunda resistência à colonialidade do poder, resistência que vai por sua vez se tornando uma potencialidade decolonial na medida em que o tecido social kaingang se fortalece através da complementariedade entre as jamré. Pois, se Marcolina escolheu Iracema

34 Iracema relatou a Clémentine Maréchal que Marcolina a tinha chamado porque sendo ela da mesma metade cosmológica que Madalena, não poderia realizar a cura ela mesma. O sistema de metades cosmológicas kaingang permeia sua práxis xamânica e modela também as relações de afinidade entre as diferentes kujà. 
para apoiar a Madalena de Paula, é porque as duas kujà são jamré, ou seja, elas pertencem a metades cosmológicas diferentes. Iracema sendo Kanheru-Kré tem a capacidade de fortalecer, através da sua diferença, a Madalena de Paula, mulher pertencendo à metade cosmológica Kamé; as forças e as substâncias trazidas por Iracema vão ter o poder de fortalecer Madalena. Marcolina, kujà que pertence à metade cosmológica Kamé - a mesma metade que Madalena -, guia/ orienta Iracema num trabalho onírico que ela mesma não poderia realizar com Madalena, porque essa kujà necessitaria de substâncias da metade oposta à sua para melhorar. A realização do sonho se torna possível porque ele é aceito pelas outras mulheres kaingang da comunidade, mas o sonho existe entre as duas kujà, Madalena de Paula e Iracema Ga Rã Nascimento, porque entre elas existe uma relação complementar própria da relacionalidade kaingang, a de jamré. Se Madalena de Paula pertencesse à mesma metade cosmológica que Iracema, Marcolina não a teria escolhido para esse trabalho. Nesse sentido, a relação entre jamré, expressão "material" do sistema de metades cosmológicas kaingang, deve ser apreendida também como formando parte do pensamento decolonial kaingang. Fugindo da matriz colonial-moderno-ocidental, as relações sociais kaingang baseadas no sistema dualista de metades cosmológicas, transmitindo-se de geração em geração, se entrelaçam nas narrativas míticas e nas práticas xamânicas para fazer frente à colonialidade, cuja expressão material mais visível encontra-se na destruição de ga, a terra. A luta pela terra kaingang está permeada por um sistema de relações sociais baseado na complementariedade e na necessidade do diferente para a constituição e o fortalecimento de si.

Os processos decoloniais tornam-se possível na medida em que se afastam de qualquer tentativa universalizante. Se podemos considerar o xamanismo como uma possibilidade decolonializadora, devemos entendê-lo antes de tudo nas especificidades ${ }^{35}$ de cada povo que o pratica. Eis aí a força do pensamento decolonial, pois, se ele supõe uma ruptura radical com o pensamento moderno-colonial, ele encontra sua origem na pluriversalidade (Mignolo, 2007). É também por esse mesmo motivo que é imprescindível, numa busca pela decolonialidade, ressaltar os saberes dos kujà kaingang nas suas especificidades a partir dos seus conceitos êmicos.

35 Porém, entendem-se essas especificidades como dinâmicas, elas vão mudando e se transformando ao fio das interações e do contato interétnico. 
Assim, os vẽnh péti das kujà, entendidos dentro de um sistema relacional próprio, são uma ferramenta decolonial que oferece novos horizontes para pensarmos a "política" kaingang e as relações de poder que a atravessam. Uma das dimensões da colonialidade do poder, segundo Quijano (2000), é a dominação e a exploração histórica dos homens sobre as mulheres, o poder patriarcal. ${ }^{36}$ Voltando ao relato da primeira kujà contado por Iracema, pode-se perceber a importância das mulheres no nascimento e nos primeiros ensinamentos dos saberes dos kujà. Esses saberes são colocados em prática em maio de 2014 através dos sonhos compartilhados entre três mulheres kujà que reafirmam tal importância. O relato da primeira kujà deve ser entendido antes de tudo como um relato em busca de ouvidoria, como uma evidência do protagonismo feminino, ele está sendo relatado com intencionalidade. Como a própria narrativa mitológica destaca:

Até há pouco tempo, Kakawej existia em Nonoai, foi nessa árvore que meu avô me levava. Kakawej tem, dentro dele, um buraco, esse é o buraco de onde saiu nossa primeira kujà. Nesse buraco é onde nós tratávamos os nossos parentes atingidos por doenças terríveis. (Trecho da narrativa mítica trazida acima, por Iracema Nascimento).

Fica evidente aqui o duplo protagonismo feminino. Além de enfatizar o protagonismo feminino na origem do xamanismo kaingang, o próprio fato do relato ser narrado por uma mulher destaca uma busca por empoderamento das mulheres kaingang enquanto protagonistas e donas da sua história.

Da mesma maneira que no relato da "onça que pega o sol", mais do que buscar "fundamentos" da sociedade ou do xamanismo kaingang nesse relato, trata-se de entender o que Iracema quer nos dizer. Pois nota-se que mais uma vez o protagonismo feminino está sendo ressaltado. Iracema devolve

36 Existe um debate muito interessante sobre a pertinência do uso do conceito de colonialidade de gênero (Lugones, 2008) entre os autores que pensam a colonialidade. Para Quijano (2000) a colonialidade do poder abrange todas as formas de dominação e exploração que podem ser analisadas de maneira interseccional (raça, gênero e classe principalmente). Em outras palavras, segundo o autor, seria impossível decolonizar o gênero sem previamente decolonizar o poder. No caso analisado aqui, a kujà Iracema, ao devolver às mulheres seu protagonismo político, decoloniza o poder, devolvendo às mulheres kaingang sua força (cosmo)política em termos próprios kaingang (como os sonhos, vẽnh péti). 
às mulheres kaingang sua potência política colocando-as como iniciadoras do xamanismo desse coletivo. Relatando essa narrativa mitológica, devolvendo ao xamanismo seu caráter profundamente político e o protagonismo político para as mulheres, Iracema torna desejos decoloniais possíveis para todo o povo kaingang. Por um lado, o relato a narrativa mítica da primeira kujà traz à história kaingang uma "nova memória", roubada e esquecida pela colonialidade do poder. Nessa "nova" memória, as mulheres são consideradas pelos Kaingang como as primeiras lideranças xamânico-políticas do seu povo. Por outro lado, as experiências vividas por Iracema em Porto Alegre e Kandóia concretizam esses desejos; sonhando para lutar e fortalecer seu povo, a liderança xamânica feminina kaingang protagonizada por Iracema é fonte de uma práxis decolonializadora que, através das suas narrativas, busca se expandir para que esses desejos decoloniais irradiem para seus demais parentes, um esforço que Iracema atribui também a tantas outras agências.

\section{Considerações finais}

Nosso esforço argumentativo pretendeu demonstrar a partir de densa descrição etnográfica os acontecimentos que relacionam as práticas xamânicas dos Kaingang em contraposição ao projeto colonial. Para isso, realizamos reflexões tanto para uma revisão do uso genérico do conceito de "xamanismo", situando localmente e visibilizando o papel das mulheres kaingang, quanto para uma valorização de conceitos e noções próprias entre os Kaingang que são imersos em práticas xamânicas, como os vẽnh péti. Um dos "problemas" no uso do "xamanismo", enquanto conceito teórico, não é tanto no conteúdo dos significados do conceito, mas na pressuposição do termo, vinculado aos povos indígenas, de maneira quase universal e descontextualizada. A nosso ver, resgatar com maior detalhamento as relações dos vẽnh péti nessas práticas, entre os Kaingang e para "fora", corrobora um outro posicionamento para o debate em torno do "xamanismo", situando essas experiências e seu horizonte cosmológico numa teia de situações coloniais, ou seja, rastreando via enredo cosmológico kaingang os projetos de contenção de processos históricos que visam sua submissão e, mesmo, seu etnocídio. Portanto, apresentamos desde a revisão de etnografias a dimensão "política" e o protagonismo das mulheres kaingang kujà 
em sua dinâmica com os sonhos, vẽnh péti. Essa ação detalha uma práxis que herda e irradia um conjunto de seres em territórios específicos, que a partir do papel mediador das kujà assumem um potencial decolonizador na atualidade. A aproximação teórico-metodológica ao debate da colonialidade do poder (Mignolo, 2007; Quijano, 2000; Quintero, 2010) foi essencial para valorizar os acontecimentos e narrativas apresentadas por nossas interlocutoras kaingang.

Os relatos míticos da kujà Iracema, sobre a captura do sol e o nascimento do xamanismo kaingang, pretendem, também, uma denúncia sobre os processos históricos de exploração de $g a$, a terra, empreendida pelos brancos em prol de uma fábula capitalista. $\mathrm{O}$ relato em torno do eclipse do sol provocado pelo mĩg, a onça, e as ações da comunidade kaingang para salvar a humanidade da escuridão demonstram tanto as formas interessadas de explicação sobre o mundo quanto a relação situada e contextualizada sobre o presente desde uma linguagem ancestral, em que o protagonismo do povo kaingang é fundamental para existência de um futuro compartilhado entre os seres de ga, neles incluindo os próprios brancos. O relato sobre o nascimento do xamanismo kaingang, ao mesmo tempo em que ressalta a importância dos sonhos para o desenvolvimento da práxis xamânica kaingang, nos deixa vislumbrar possibilidades decolonizadoras do poder. Devolvendo, a partir de conceitos e termos próprios, o poder político às mulheres, aqui, protagonistas do nascimento e da perpetuação do xamanismo kaingang, o relato da primeira kujà deve ser entendido como um impulso decolonial.

A releitura de etnografias publicadas nos permitiu reforçar o entendimento presente em nossas próprias etnografias, do caráter potencial dos vẽnh péti como um dos elementos da cosmopolítica kaingang, em que sua prática movimenta-se e dinamiza-se como horizonte decolonial. Os acontecimentos envolvendo e sendo envolvidos pela kujà Iracema, em distintos contextos de luta e defesa dos Kaingang, centram esforços nessa prática xamânica, que é tecida num território amplo, orientada pelos antepassados, outras kujà, seres extra-humanos, em seus mundos - visíveis e invisíveis - interessados, também, em solucionar a subjugação e extermínio dos Kaingang.

Contudo, os relatos dos nossos "interlocutores" kaingang são relatos que buscam (e merecem) ser ouvidos, pois simultaneamente atuam como (re)construtores de uma memória decolonizada, e visibilizam ações de resistência, de caráter ancestral, diante dos processos coloniais históricos e contemporâneos. 
Não podemos negar que enquanto antropólogos, é nossa devida responsabilidade (e hoje mais do que nunca) buscar novas maneiras de contribuir com a luta indígena. Para isso, é preciso também fazermos um esforço para nos desprender do nosso pensamento enraizado em séculos de racionalidade moderna. Este artigo buscou, nesse sentido, ser uma contribuição para pensarmos a luta kaingang além da dimensão jurídico-política incorporada pela racionalidade moderna. Como bem disse Quijano (1990, p. 32, tradução nossa): “A vida está feita da mesma madeira da dos sonhos."

\section{Referências}

ALBERT, B. O ouro canibal e a queda do céu: uma crítica xamânica da economia política da natureza. Brasília: UnB, 1995. (Série Antropológica, 174).

ANZALDÚA, G. Borderlands/La frontera. [S.1.]: [s.n.], 1987.

AQUINO, A. de M. Ën ga uyg ën tóg ("nós conquistamos nossa terra"): os Kaingang no litoral do Rio Grande do Sul. 2008. Dissertação (Mestrado em Antropologia Social)Departamento de Antropologia Social, Universidade de Brasília, Brasília, 2008.

BALANDIER, G. La situation coloniale: approche théorique. Cahiers internationaux de sociologie, n. 11, p. 44-79, 1951.

BORBA, T. M. Actualidade indigena. Curitiba: Imprensa Paranaense, 1908.

CARVALHO, P. R. “Para deixar crescer e existir": sobre a construção de corpos e pessoas Kaingang. 2011. Dissertação (Mestrado em Antropologia Social)-Departamento de Antropologia Social, Universidade de Brasília, Brasília, 2011.

CHAUMEIL, J.-P. Voir savoir pouvoir: le chamanisme chez les Yagua de l'Amazonie péruvienne. Genève: Georg Editeur, 2000.

CLASTRES, P. Do etnocídio. In: CLASTRES, P. Arqueologia da violência. 3. ed. São Paulo: Cosac Naify, 2014. p. 75-87.

CLAUDINO, Z. K. A formação da pessoa nos pressupostos da tradição: educação indígena kaingang. 2013. Dissertação (Mestrado em Educação)-Faculdade de Educação, Universidade Federal do Rio Grande do Sul, Porto Alegre, 2013.

COMUNIDADE KANDÓIA/VOTOURO. Pronunciamento da comunidade Kandóia/ Votouro. Espaço Ameríndio, Porto Alegre, v. 8, n. 1, p. 249-251, 2014. 
COSTA, C. de L. Feminismos descoloniais para além do humano. Estudos Feministas, Florianópolis, v. 22, n. 3, p. 929-934, 2014.

CRÉPEAU, R. R. Mythe et rituel chez les indiens kaingang du Brésil Méridional. Religiologiques, Paris, n. 10, p. 143-157, 1994.

CRÉPEAU, R. R. La pratique du chamanisme chez les Kaingang du Brésil méridional - une brève comparaison avec le chamanisme bororo. In: AIGLE, D. La politique des esprits. Nanterre: Société d'ethnologie, 2000. p. 309-322.

CRÉPEAU, R. R. “Os Kamé vão sempre primeiro”: dualismo social e reciprocidade entre os Kaingang. Anuário Antropológico/2005, Rio de Janeiro, p. 9-33, 2006.

FERNANDES, R. C. Política e parentesco entre os Kaingang: uma análise etnológica. 2003. Tese (Doutorado em Antropologia Social)-Faculdade de Filosofia, Letras e Ciências Humanas, Universidade de São Paulo, São Paulo, 2003.

GROISMAN, A. O Santo Daime e a nova peregrinação. Estudos Leopoldenses, São Leopoldo, v. 32, n. 146, p. 111-119, 1996.

GROSFOGUEL, R. Descolonizando los universalismos occidentales: el pluri-versalismo transmoderno decolonial desde Aimé Césaire hasta los zapatistas. In: CASTRO GOMEZ, S.; GROSFOGUEL, R. (Ed). El giro decolonial: reflexiones para una diversidad epistémica más allá del capitalismo global. Bogotá: Siglo del Hombre, 2007. p. 63-77.

GROSFOGUEL, R. La descolonización del conocimiento: diálogo crítico entre la visión descolonial de Franz Fanon y la sociología descolonial de Boaventura de Sousa Santos. In: VIANELLO, A.; MAÑÉ, B. (Coord.). Formas-otras: saber, nombrar, narrar, hacer. Barcelona: CIDOB, 2011. p. 97-108.

HERMANN, H. W. No coração da cidade: cosmopolítica, dinheiro e afeto na luta kanhgág pelo espaço em Porto Alegre-RS. 2016. Dissertação (Mestrado em Antropologia Social)-Instituto de Filosofia e Ciências Humanas, Universidade Federal do Rio Grande do Sul, Porto Alegre, 2016.

KRENAK, A. Paisagens, territórios e pressão colonial. Espaço Ameríndio, Porto Alegre, v. 9, n. 3, p. 327-343, 2015.

LANGDON, E. J. M. Introdução: xamanismo - velhas e novas perspectivas. In: LANGDON, E. J. M. (Org.). Xamanismo no Brasil: novas perspectivas. Florianópolis: Editora da UFSC, 1996. p. 9-37.

LÉVI-STRAUSS, C. Mito e significado. Lisboa: Edições 70, 2007.

LIMA, T. S. Por uma cartografia do poder e da diferença nas cosmopolíticas ameríndias. Revista de Antropologia, São Paulo, v. 54, n. 2, p. 601-646, 2011. 
LUGONES, M. Colonialidad y género: hacia un feminismo descolonial. In: MIGNOLO, W. (Org.). Género y descolonialidad. Buenos Aires: Del Signo, 2008. p. 13-42.

MARÉCHAL, C. "Eu luto desde que me conheço como gente": territorialidade e cosmopolítica kanhgág enfrentando o poder colonial no sul do Brasil. 2015. Dissertação (Mestrado em Antropologia Social)-Instituto de Filosofia e Ciências Humanas, Universidade Federal do Rio Grande do Sul, Porto Alegre, 2015.

MARÉCHAL, C. Sonhar, curar, lutar: colonialidade, xamanismo e cosmopolítica kaingang no Rio Grande do Sul. Curitiba: Prismas, 2018.

MIGNOLO, W. El pensamiento decolonial: desprendimiento y apertura. Un manifiesto. In: CASTRO GOMEZ, S.; GROSFOGUEL, R. (Ed.). El giro decolonial: reflexiones para una diversidad epistémica más allá del capitalismo global. Bogotá: Siglo del Hombre, 2007. p. 25-46.

NASCIMENTO, I. G. R. et al. Minha missão no mundo. Espaço Ameríndio, Porto Alegre, v. 11, n. 2, p. 336-364, 2017.

OLIVEIRA, J. P. de. Uma etnologia dos “índios misturados"? Situação colonial, territorialização e fluxos culturais. Mana, Rio de Janeiro, v. 4, n. 1, p. 47-77, abr. 1998.

PERRIN, M. Formes de la communication chamanique. Exemple Guajiro. In: REICHEL, E. D. (Comp.). Rituales y fiestas de las Américas: $45^{\circ}$ Congreso Internacional de Americanistas. Bogotá: Uniandes, 1988. p. 208-217.

QUIJANO, A. Estética de la utopía. Hueso Húmero, Lima, n. 27, p. 32-42, 1990.

QUIJANO, A. Colonialidad del poder y clasificación social. Journal of World-System Research, Riverside, v. 11, n. 2, p. 342-386, 2000.

QUINTERO, P. Notas sobre la teoria de la colonialidad del poder y la estructuración de la sociedad en América Latina. Papeles de Trabajo, Rosario, n. 19, p. 1-15, 2010.

QUINTERO, P. (Comp.). Alternativas descoloniales al capitalismo colonial/moderno. Buenos Aires: Ediciones del Signo, 2015a.

QUINTERO, P. Mito-lógicas del diablo en el Chaco argentino. Espaço Ameríndio, Porto Alegre, v. 9, n. 1, p. 239-262, 2015b.

ROSA, R. R. G. Os kujà são diferentes: um estudo etnológico do complexo xamânico dos Kaingang da terra indígena Votouro. 2005. Tese (Doutorado em Antropologia Social)-Instituto de Filosofia e Ciências Humanas, Universidade Federal do Rio Grande do Sul, Porto Alegre, 2005.

ROSA, R. R. G. Mitologia e xamanismo nas Relações Sociais dos Inuit e dos Kaingang. Espaço Ameríndio, Porto Alegre, v. 5, n. 3, p. 98-122, 2011. 
ROSA, R. R. G. O xamanismo kaingang, o poder e a floresta: uma análise da relação dos kujà (xamãs) com seus jagrë e santos do panteão do catolicismo popular. In: FLECK, E. C. D. (Org.). Religiões e religiosidades no Rio Grande do Sul: manifestações da religiosidade indígena. São Paulo: ANPUH, 2014. v. 3, p. 97-128.

SILVA, S. B. da. Dualismo e cosmologia kaingang: o xamã e o domínio da floresta. Horizontes Antropológicos, Porto Alegre, ano 8, n. 18, p. 188-209, 2002.

SILVA, S. B. da. Cosmo-ontologia e xamanismo entre coletivos kaingang. In: FLECK, E. C. D. (Org.). Religiões e religiosidades no Rio Grande do Sul: manifestações da religiosidade indígena. São Paulo: ANPUH, 2014. v. 3, p. 69-96.

STENGERS, I. The cosmopolitical proposal. In: LATOUR, B.; WEIBEL, P. (Ed.). Making things public. Cambridge: MIT Press, 2005. p. 994-1003.

VALENTE, R. Os fuzis e as flechas: história de sangue e resistência indígena na ditadura. São Paulo: Companhia das Letras, 2017.

VEIGA, J. Cosmologia e práticas rituais kaingang. 2000. Tese (Doutorado em Antropologia Social)-Instituto de Filosofia e Ciências Humanas, Universidade Estadual de Campinas, Campinas, 2000.

VIVEIROS DE CASTRO, E. A inconstância da alma selvagem: e outros ensaios de antropologia. São Paulo: Cosac Naify, 2002.

Recebido: 29/05/2017 Aceito: 14/03/2018 | Received:5/29/2017 Accepted: 3/14/2018 